Article

\title{
Genome-Wide Survey Indicates Diverse Physiological Roles of Dendrobium officinale Calcium-Dependent Protein Kinase Genes
}

\author{
Xingyu Yang ${ }^{1,2,3,4,+}$, Zhiyu Chen ${ }^{1,2,3,4,+}$, Xin Yin ${ }^{1,2}$, Yuhua Wang ${ }^{3} \mathbb{D}$, Yunqiang Yang ${ }^{1,2, *}$ \\ and Yongping Yang ${ }^{1,2, *(\mathbb{D})}$
}

check for updates

Citation: Yang, X.; Chen, Z.; Yin, $X . ;$

Wang, Y.; Yang, Y.; Yang, Y.

Genome-Wide Survey Indicates Diverse Physiological Roles of Dendrobium officinale Calcium-

Dependent Protein Kinase Genes. Int. J. Mol. Sci. 2022, 23, 1298

https://doi.org/10.3390/ ijms23031298

Academic Editors: Wenpan Dong and Shiliang Zhou

Received: 15 November 2021

Accepted: 21 January 2022

Published: 24 January 2022

Publisher's Note: MDPI stays neutral with regard to jurisdictional claims in published maps and institutional affiliations.

Copyright: (C) 2022 by the authors. Licensee MDPI, Basel, Switzerland. This article is an open access article distributed under the terms and conditions of the Creative Commons Attribution (CC BY) license (https:// creativecommons.org/licenses/by/ $4.0 /)$
1 The Germplasm Bank of Wild Species, Kunming Institute of Botany, Chinese Academy of Sciences, Kunming 650201, China; yangxingyu@mail.kib.ac.cn (X.Y.); chenzhiyu@mail.kib.ac.cn (Z.C.); yinxin@mail.kib.ac.cn (X.Y.)

2 Institute of Tibetan Plateau Research at Kunming, Kunming Institute of Botany, Chinese Academy of Sciences, Kunming 650201, China

3 Key Laboratory of Economic Plants and Biotechnology, Kunming Institute of Botany, Chinese Academy of Sciences, Kunming 650201, China; wangyuhua@mail.kib.ac.cn

4 Academy of Biological Sciences, University of Chinese Academy of Sciences, Beijing 100049, China

* Correspondence: yangyunqiang@mail.kib.ac.cn (Y.Y.); yangyp@mail.kib.ac.cn (Y.Y.)

+ These authors contributed equally to this work.

\begin{abstract}
Calcium-dependent protein kinases (CDPKs) are crucial calcium ions $\left(\mathrm{Ca}^{2+}\right)$ sensors in plants with important roles in signal transduction, plant growth, development, and stress responses. Here, we identified 24 genes encoding CDPKs in Dendrobium officinale using genome-wide analysis The phylogenetic analysis revealed that these genes formed four groups, with similar structures in the same group. The gene expression patterns following hormone treatments and yeast two-hybrid of homologous CDPK gene pairs with Rbohs showed differences, indicating functional divergence between homologous genes. In addition, the rapid accumulation of hydrogen peroxide $\left(\mathrm{H}_{2} \mathrm{O}_{2}\right)$ and stomatal closure was observed in response to salicylic acid (SA)/jasmonic acid (JA) stress. Our data showed that CDPK9-2 and CDPK20-4 interacted with Rboh D and Rboh H, respectively, and were implicated in the generation of $\mathrm{H}_{2} \mathrm{O}_{2}$ and regulation of the stomatal aperture in response to salicylic acid/jasmonic acid treatment. We believe these results can provide a foundation for the functional divergence of homologous genes in D. officinale.
\end{abstract}

Keywords: Dendrobium officinale; CDPK gene family; expression pattern; functional divergence

\section{Introduction}

Because plants are immobile, they have evolved several mechanisms and signaling networks to recognize and resist various stresses, such as drought, salinity, and pathogen attack [1]. As one of the most widely studied second messengers, calcium ions $\left(\mathrm{Ca}^{2+}\right)$ play an indispensable role in signaling pathways [2]. Signal transduction pathways mediated by $\mathrm{Ca}^{2+}$ are known to target different proteins functioning in various biological processes. For example, signal transduction pathways targeting enzymes can affect cell metabolism, whereas those targeting cytoskeletal proteins affect cell morphology and movement. Three types of $\mathrm{Ca}^{2+}$-binding proteins, namely calmodulins (CaMs), calmodulin-like proteins, and calcineurin B-like proteins, or $\mathrm{Ca}^{2+}$ sensors encoding calcium-dependent protein kinases $(C D P K s)$ detect changes in cellular $\mathrm{Ca}^{2+}$ concentrations. These molecules initiate multiple reactions in response to diverse stimuli in plants [3-6]. CDPKs have been widely studied because they can directly bind $\mathrm{Ca}^{2+}$ in a CaM-independent manner. Previous studies have demonstrated that CDPKs are absent in humans, fungi, and insects but are widely found in plants $[7,8]$. CDPKs contain four important conserved domains including the N-terminal variable domain that contains palmitoylation or myristoylation sites and allows 
the CDPK to locate correctly. The Ser/Thr kinase domain that binds to ATP is involved in autophosphorylation; the autoinhibitory domain is speculated to be a part of the CaM-like domain; and a CaM-like regulatory domain with from one to four EF-hands has been implicated in $\mathrm{Ca}^{2+}$ binding [9-17].

CDPKs are abundantly present in several plant species; $28,17,31$, and $25 C D P K$ genes are present in barley, grapevine, pepper, and maize, respectively [18-21]. Previous studies have demonstrated the responses of CDPKs to multiple stress stimuli. In cotton, GrCDPK14 is significantly upregulated following $12 \mathrm{~h}$ of cold stress [22]. Treatment with varying concentrations of methyl jasmonate (MeJA) upregulates the expression of RcCDPK3/7/10/11 [23]. The functional diversification of CDPKs, detected by other studies, depends on their interactions with different molecular targets $[16,24,25]$. Among them, RcCDPK 1/4/5/13/14 interacts with $\mathrm{rolB} / \mathrm{C}$ to regulate the formation of callus in the cultures of Rubia cordifolia. Tobacco CDPK1 interacts with the repression of shoot growth (RSG) to regulate the gibberellin (GA) pathways $[23,26]$. In strawberry, FaCDPKs interact with respiratory burst oxidase homolog (Rboh), another target of CDPK to generate hydrogen peroxide $\left(\mathrm{H}_{2} \mathrm{O}_{2}\right)$ in response to drought stress [27]. In rice, OsCDPK5/11 interacts with Rboh $\mathrm{H}$, resulting in the accumulation of reactive oxygen species (ROS) under oxygendeficient conditions [28]. Similarly, StCDPK4/5 phosphorylates StRboh to activate ROS production in response to stress in potato leaves [29].

Dendrobium officinale (Kimura and Migo) is a rare and precious Chinese medicinal herb that usually grows on cliffs in diverse habitats [30-32]. D. officinale is the third largest genus in the Orchidaceae family [33]. It has been exploited for its medicinal value, such as immunity-enhancing property, since the Tang dynasty [34]. Over the past 20 years, researchers have been trying to transform it from an endangered plant to one for use on an industrial scale [35]. However, these plants are still vulnerable to several stresses. Although CDPKs are known to regulate stress responses and resistance, their roles have not been explored in D. officinale. In this study, we identified CDPK genes in the $D$. officinale genome and analyzed their phylogenetic relationships and expression patterns. In addition, we studied their functional divergence by analyzing interactions of DoCDPKs and DoRbohs following hormone treatments. Our results revealed the functional divergence of homologous genes and the biological function of the D. officinale CDPK gene family.

\section{Results}

\subsection{Identification of 24 CDPK Genes in D. officinale}

Thirty-five proteins were filtered and extracted by TBtools [36]. After removing shorter alternative splice variants, 24 proteins were identified as DoCDPKs and were numbered according to the phylogenetic relationship (Figure S1) and protein identity (Table S1) with CDPKs from Arabidopsis thaliana. The molecular weight of CDPKs (Table 1) ranged from $35.07 \mathrm{kDa}$ (DoCDPK13-2) to $65.73 \mathrm{kDa}$ (DoCDP20-3). The isoelectric point was approximately 5-6.7, except for DoCDPK16, which was 8.08. The majority of DoCDPKs (18 out of 24) had four EF-hand motifs, all of which had a palmitoylation site. However, less than half of them had a myristoylation site, and only DoCDPK3-2 had an N-terminal acylation site. Homologous gene pairs displayed similar molecular weights, isoelectric points, and domain structures. For example, the molecular weights of DoCDPK20-1, 20-2, 20-3, and 20-4 were 64.82, 65.73, 63.92, and $63.92 \mathrm{kDa}$, respectively. The isoelectric points of DoCDPK20-1, 20-2, 20-3 was 5.15, except for DoCDPK20-4, which was 5.51. All four proteins had palmitoylation sites. These results suggested a similar biological role of homologous gene pairs.

\subsection{Phylogenetic and Gene Structure Analyses of DoCDPKs}

Phylogenetic analysis divided the $24 C D P K$ of $D$. officinale genes into four groups (Figure 1). Group 4 had the fewest DoCDPK members (three), whereas the number of $C D P K s$ in the other three groups ranged from six to nine. Gene structural analyses revealed that genes within the same group had similar numbers and lengths of exons. The length of 
introns varied within and among groups, ranging from $<1$ to $>25 \mathrm{~kb}$. In terms of intron phases, the first intron was highly conserved in phase-0; however, the majority of fourth introns were in phase-2 in genes in group 1-3. For genes in group 4, the first intron was in phase- 0 , and the last intron was in phase- 1 . The complex structure of group 4 genes could be indicative of different divergence times, suggesting functional differences between DoCDPKs in group 4 and those in the other three groups.

Table 1. Characteristics of CDPK in Dendrobium officinale.

\begin{tabular}{|c|c|c|c|c|c|c|c|c|c|}
\hline Gene Name & ACC.NO. & CDS (bp) & EF Hands & MW (Kda) & PI & GRAVY & $\mathbf{M}$ & $\mathbf{P}$ & $\mathrm{T}$ \\
\hline DoCDPK6-1 & XP_020676095.1 & 1665 & 4 & 61.72 & 5.74 & -0.228 & $\mathrm{~N}$ & $\mathrm{Y}$ & $\mathrm{N}$ \\
\hline DoCDPK6-3 & XP_028549092.1 & 1665 & 4 & 62.11 & 5.55 & 0.288 & $\mathrm{~N}$ & $\mathrm{Y}$ & $\mathrm{N}$ \\
\hline DoCDPK6-2 & XP_020702402.1 & 1683 & 4 & 61.84 & 5.45 & -0.254 & $\mathrm{Y}$ & $\mathrm{Y}$ & $\mathrm{N}$ \\
\hline DoCDPK11-1 & XP_020685368.1 & 1494 & 4 & 56.03 & 5.43 & -0.339 & $\mathrm{~N}$ & $\mathrm{Y}$ & $\mathrm{N}$ \\
\hline DoCDPK11-2 & XP_020689725.1 & 1488 & 4 & 55.64 & 5.39 & -0.315 & $\mathrm{~N}$ & $\mathrm{Y}$ & $\mathrm{N}$ \\
\hline DoCDPK20-1 & XP_020694473.1 & 1752 & 4 & 64.82 & 5.15 & -0.344 & $\mathrm{~N}$ & $\mathrm{Y}$ & $\mathrm{N}$ \\
\hline DoCDPK20-4 & XP_020692403.1 & 1725 & 4 & 63.92 & 5.51 & -0.313 & $\mathrm{~N}$ & $\mathrm{Y}$ & $\mathrm{N}$ \\
\hline DoCDPK20-3 & XP_020684094.1 & 1773 & 4 & 65.7 & 5.15 & -0.318 & $\mathrm{~N}$ & $\mathrm{Y}$ & $\mathrm{N}$ \\
\hline DoCDPK20-2 & XP_028550805.1 & 1764 & 4 & 65.73 & 5.15 & -0.318 & $\mathrm{~N}$ & $\mathrm{Y}$ & $\mathrm{N}$ \\
\hline DoCDPK34 & XP_020691369.2 & 1440 & 4 & 54.19 & 5.71 & -0.385 & $\mathrm{~N}$ & $\mathrm{Y}$ & $\mathrm{N}$ \\
\hline DoCDPK3-2 & XP_020673496.1 & 1536 & 4 & 57.19 & 5.71 & -0.385 & $\mathrm{~N}$ & $\mathrm{Y}$ & $\mathrm{N}$ \\
\hline DoCDPK3-1 & XP_020700773.1 & 1566 & 4 & 58.17 & 5.84 & -0.411 & $\mathrm{~N}$ & $\mathrm{Y}$ & $\mathrm{N}$ \\
\hline DoCDPK29 & XP_020691445.1 & 1563 & 4 & 58.58 & 6.23 & -0.365 & $\mathrm{Y}$ & $\mathrm{Y}$ & $\mathrm{N}$ \\
\hline DoCDPK9-2 & XP_020688324.1 & 1578 & 4 & 58.33 & 5.94 & -0.432 & Y & $\mathrm{Y}$ & $\mathrm{N}$ \\
\hline DoCDPK9-1 & XP_020698035.1 & 1605 & 4 & 59.67 & 6.03 & -0.477 & $\mathrm{Y}$ & $\mathrm{Y}$ & $\mathrm{N}$ \\
\hline DoCDPK24 & XP_020688637.2 & 1302 & 4 & 49.42 & 5.35 & -0.398 & $\mathrm{~N}$ & $\mathrm{Y}$ & $\mathrm{N}$ \\
\hline DoCDPK13-1 & XP_020684921.1 & 1329 & 3 & 60.46 & 6.14 & -0.457 & $\mathrm{~N}$ & $\mathrm{Y}$ & $\mathrm{N}$ \\
\hline DoCDPK13-2 & XP_028548644.1 & 930 & 3 & 35.07 & 5.02 & -0.468 & $\mathrm{~N}$ & $\mathrm{Y}$ & $\mathrm{N}$ \\
\hline DoCDPK7 & XP_020678675.1 & 1608 & 3 & 60.13 & 6.38 & -0.414 & $\mathrm{~N}$ & $\mathrm{Y}$ & $\mathrm{N}$ \\
\hline DoCDPK8-2 & XP_020682170.1 & 1611 & 4 & 60.3 & 6.46 & -0.476 & $\mathrm{Y}$ & $\mathrm{Y}$ & $\mathrm{N}$ \\
\hline DoCDPK8-1 & XP_020698328.1 & 1608 & 3 & 60.35 & 6.32 & -0.464 & $\mathrm{Y}$ & $\mathrm{Y}$ & $\mathrm{N}$ \\
\hline DoCDPK28-1 & XP_020702698.1 & 1605 & 3 & 60.63 & 6.7 & -0.419 & $\mathrm{Y}$ & $\mathrm{Y}$ & $\mathrm{N}$ \\
\hline DoCDPK16 & XP_028552413.1 & 1716 & 3 & 64.42 & 8.08 & -0.585 & Y & $\mathrm{Y}$ & $\mathrm{N}$ \\
\hline DoCDPK28-2 & XP_020676625.1 & 1545 & 4 & 57.52 & 5.84 & -0.204 & $\mathrm{~N}$ & $\mathrm{Y}$ & $\mathrm{N}$ \\
\hline
\end{tabular}

ACC.NO., Genebank Accession Number. CDS, length of CDS. EF hands, number of EF hands. GRAVY, grand average of hydropathicity; M, myristoylation site, P, palmitoylation site; T, N-terminal acylation; N, NO; Y, YES.

\subsection{Natural Selection Estimation and Conserved Motif Analysis}

To further explore the evolutionary relationships of DoCDPKs, DoCDPK homology gene pairs were compared to evaluate their phylogenetic relationships (Table 2). At the amino acid level, the protein identity of homologous gene pairs ranged from $69.60 \%$ between DoCDPK3-2 and DoCDPK3-1 to 87.53\% between DoCDPK11-1 and DoCDPK11-2, except DoCDPK 13-1/2, because DoCDPK 13-2 was considerably shorter. The average identity between proteins was the highest in group $1(82.05 \%)$ and the lowest in group 4 $(70.23 \%)$. We calculated the ratio of nonsynonymous $(\mathrm{Ka})$ and synonymous (Ks) substitutions. Both the $\mathrm{Ka} / \mathrm{Ks}$ ratio of each pair and the average $\mathrm{Ka} / \mathrm{Ks}$ ratio $(0.1042)$ were less than 1, suggesting that DoCDPKs underwent purifying selection. Next, to gain insight into gene function, 20 conserved motifs were predicted using the MEME software (Figure 2). More than half of the detected motifs were associated with kinase and EF-hand activity. According to the predicted conserved domain analysis, the Ser/Thr protein kinase domain was composed of motifs 3-9, and the four EF-hand motifs were composed of motifs 10, 11,13 , and 15 . The motifs in group 4 were conserved in every group. Motifs 12 and 14 were present in all members of group 3, and each group had at least one specific motif. The DoCDPKs in group 1 contained the highest number of motifs (up to 17), whereas those in the other three groups had approximately 15, 15, and 11 motifs, respectively. These results indicate that apart from the main functions of DoCDPKs, a certain level of functional divergence also exists. 


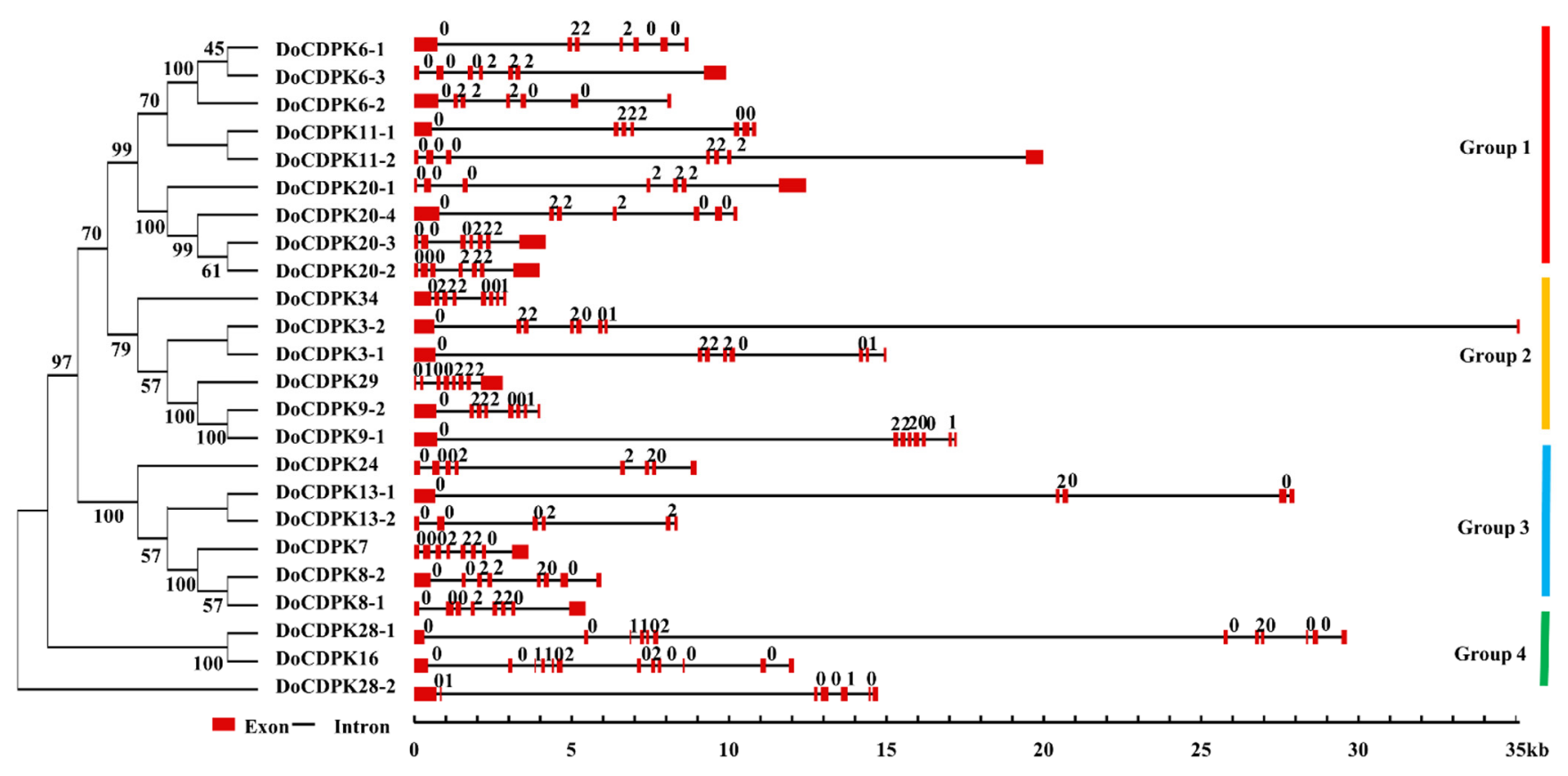

Figure 1. Phylogenetic relationship and gene structure of D. officinale CDPKs. A neighbor-joining tree was created using full-length protein sequences of 24 DoCDPKs using MEGAX 7.0 with 1000 bootstrap replicates. Numbers beside branches indicate bootstrap support. Red rectangles and black lines represent exons and introns, respectively. The number on lines indicates the intron phase. Four groups (1-4) are displayed in different colors.

Table 2. Estimated natural selection of D. officinale CDPK homologous gene pairs.

\begin{tabular}{cccccc}
\hline Seq_1 & Seq_2 & Identity (\%) & Ka & Ks & $\boldsymbol{\omega}$ \\
\hline DoCDPK6-1 & DoCDPK6-3 & 86.10 & 0.0942 & 1.0008 & 0.0941 \\
DoCDPK6-1 & DoCDPK6-2 & 81.13 & 0.0751 & 0.6947 & 0.1081 \\
DoCDPK6-2 & DoCDPK6-3 & 79.86 & 0.0895 & 0.8868 & 0.1009 \\
DoCDPK11-1 & DoCDPK11-2 & 87.53 & 0.0630 & 0.9029 & 0.0698 \\
DoCDPK20-3 & DoCDPK20-4 & 81.19 & 0.0909 & 0.7991 & 0.1138 \\
DoCDPK20-3 & DoCDPK20-2 & 80.34 & 0.1071 & 1.0135 & 0.1057 \\
DoCDPK20-2 & DoCDPK20-4 & 78.23 & 0.1137 & 0.8833 & 0.1287 \\
DoCDPK3-2 & DoCDPK3-1 & 69.60 & 0.1943 & 1.5219 & 0.1277 \\
DoCDPK9-2 & DoCDPK9-1 & 83.02 & 0.0738 & 0.7152 & 0.1033 \\
DoCDPK13-1 & DoCDPK13-2 & 49.72 & 0.1970 & 1.1168 & 0.1708 \\
DoCDPK7 & DoCDPK8-2 & 86.19 & 0.0793 & 0.8846 & 0.0897 \\
DoCDPK7 & DoCDPK8-1 & 85.23 & 0.0848 & 0.8835 & 0.0960 \\
DoCDPK8-2 & DoCDPK8-1 & 87.50 & 0.0659 & 0.8111 & 0.0813 \\
DoCDPK28-1 & DoCDPK16 & 70.23 & 0.1502 & 2.1678 & 0.0693 \\
\hline
\end{tabular}

$\mathrm{Ka}$, nonsynonymous substitution rate; Ks, synonymous substitution rate; $\omega, \mathrm{Ka} / \mathrm{Ks}$.

\subsection{Transcription Profiles of DoCDPKs in Different Tissues}

To better understand the connection between evolution and the functional divergence of $D o C D P K s$, we analyzed the levels of gene transcript levels in different tissues (Figure 3). Certain CDPKs were expressed specifically in one tissue, among which DoCDPK24 was only detected in the pollinium. Certain DoCDPKs, such as DoCDPK8-2, were detected in all 10 analyzed tissues. DoCDPK20-1, 29, 13-2, 28-1, and 28-2 exhibited the opposite expression patterns in vegetative organs and reproductive organs, except for the pollinium, whereas others displayed the same expression pattern in vegetative and reproductive organs. Although DoCDPK34 was not expressed in the stem, it was abundantly expressed in other tissues. Genes in the same group or closely related gene pairs often had different expression patterns. For example, the homologous genes DoCDPK6-1/-2/-3 in group 1 
showed highly different expression patterns among the tested tissues. As mentioned above, the expression of different DoCDPKs in different tissues reflected their diverse functions during both vegetative and reproductive growth. This result is indicative of functional divergence between homologous gene pairs.

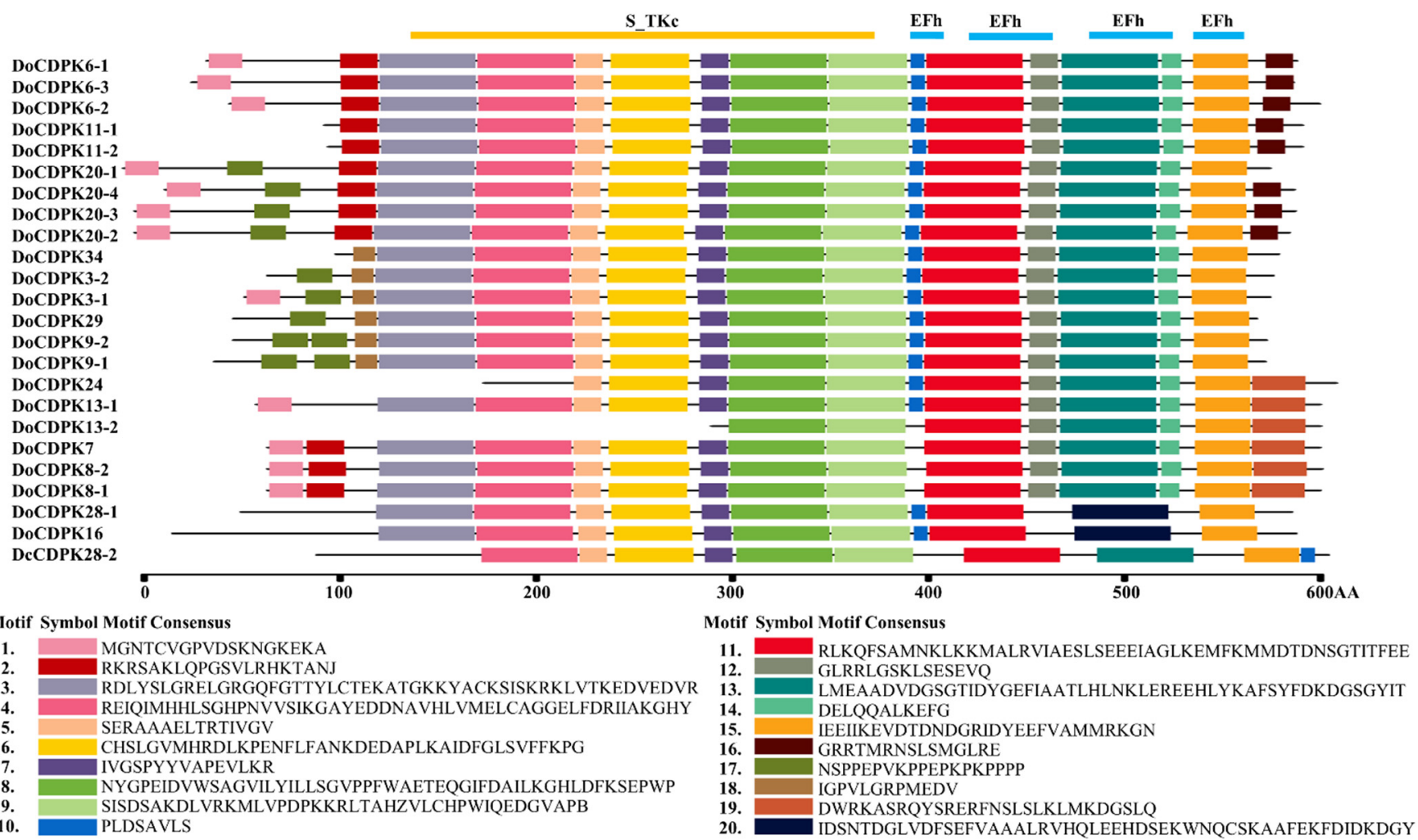

Figure 2. Motif organization in members of the CDPK gene family in D. officinale. Conserved motifs were predicted using the MEME software (meme-suite.org). Different motifs are marked by differently colored rectangles. Yellow and blue bar indicate conserved protein kinase domain and EF-hand motif, respectively.

\subsection{Prediction of Cis-Acting Elements and Gene Expression Patterns under Different Hormone Treatments}

Previous studies have reported that several hormone stimuli regulate the expression of CDPKs. Therefore, we predicted cis-acting elements in the promoter regions (2000 bp upstream of the start codon) of CDPK genes. Although the distribution of cis-acting elements in the promoter regions of CDPKs (Figure 4A) varied widely, all CDPKs contained elements related to hormone responsiveness. The promoters of more than half of the CDPKs had elements involved in response to abscisic acid (ABA), jasmonic acid (JA), and auxin (indole acetic acid, IAA). In addition, 6 out of 24 genes had elements related to salicylic acid (SA) response.

Next, we explored the expression patterns of CDPK genes in the leaves of plants under different hormone treatments using data downloaded from the internet. The results of quantitative-polymerase chain reaction (q-PCR) of DoCDPK6-1, DoCDPK11-1 and DoCDPK29 showed the same trend as the heat map (Figure S2). Although gene transcript levels in leaves were at moderate to low levels under natural conditions, these changed markedly after spraying with different hormones. The transcript levels of all CDPK genes were altered at 3 and $6 \mathrm{~h}$ following hormone treatment. The majority of genes were upregulated at $3 \mathrm{~h}$, followed by a gradual return to the initial level at $6 \mathrm{~h}$ after hormone treatments. Of the 24 CDPK genes, 20, 15, 21, and 17 genes were upregulated following treatment with SA, ABA, IAA, and JA, respectively. After treatment with SA, CDPKs were upregulated, 
with $10 C D P K$ genes showing peak expression. Most of them had SA-response elements in their promoter regions. Similarly, most of the upregulated genes in response to JA had cis-acting elements in their promoter regions that were involved in JA response. These results suggested that different genes with different cis-acting elements in their promoter regions participate in distinct pathways to regulate stress resistance in $D$. officinale.

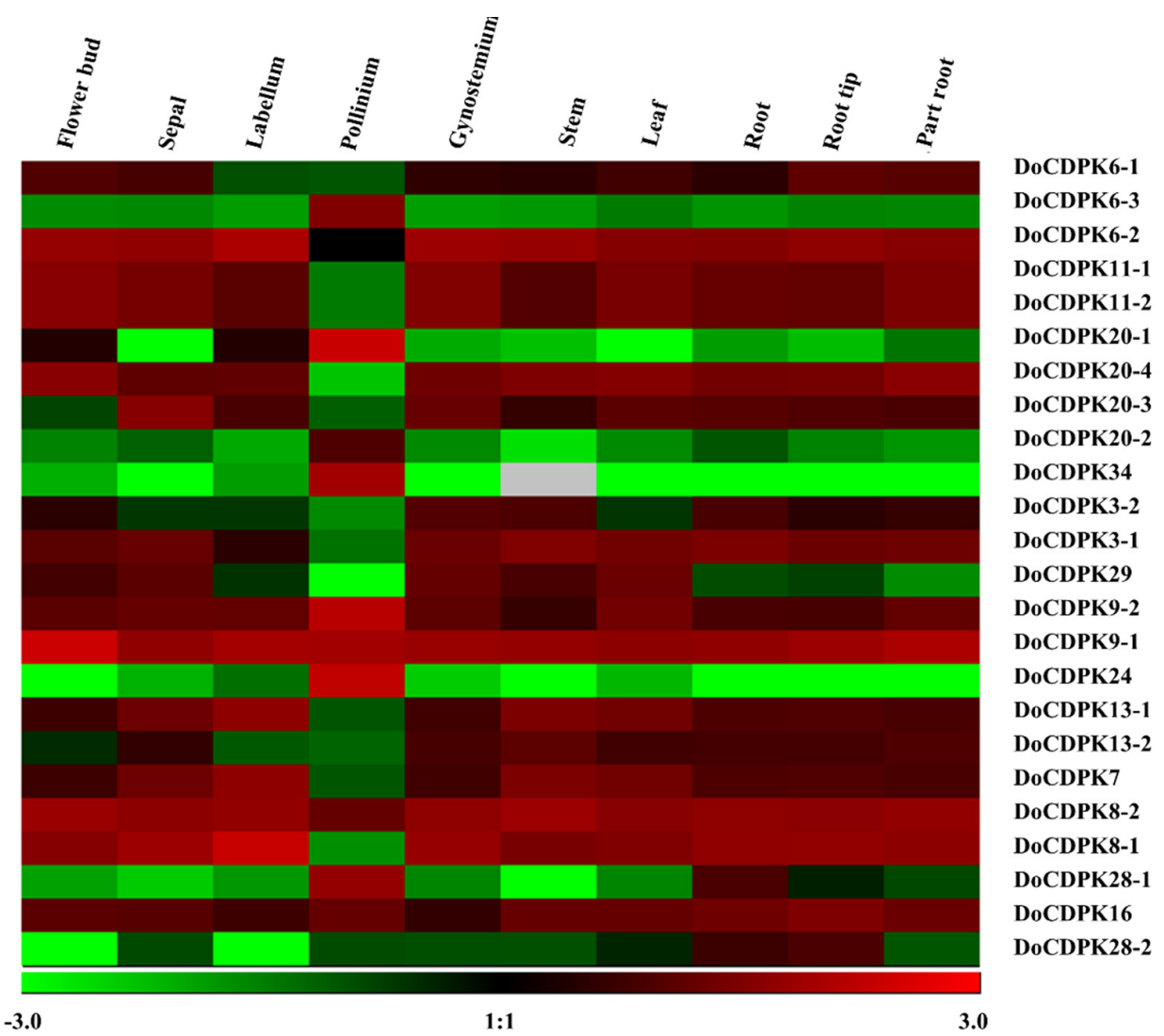

Figure 3. Expression patterns of DoCDPK genes in different organs of D. officinale. Data for the transcript levels of DoCDPKs using the FPKMs value (fragments per kilobase of exon model per million mapped fragments) downloaded from the Dendrobium gene expression database (ncku.edu.tw). A heatmap was generated using the Genesis software. Parameters were set as log 10 transformation, and genes were normalized. High, moderate, and low expression of one gene is shown in red, black, and green, respectively, in different tissues. Gray represents the FPKM value of 0.

\subsection{Interaction between Rbohs and CDPKs}

Rboh proteins are known substrates of CDPK and are related to ROS generation under stress. Previous results have shown that the expression of DoCDPK9-1/-2 and DoCDPK20$1 / 2 / 3 / 4$ was increased after treatment with hormones. Yeast two-hybrid analyses (Figure 5) were conducted to assess the interaction between these proteins in D. officinale. In addition, the content of $\mathrm{H}_{2} \mathrm{O}_{2}$ (Figure 6A,B) and changes in stomatal aperture (Figure 6C,D), which are related to stress resistance, were determined. To clarify the relationship between stomatal behavior and hormone treatments, $\mathrm{H}_{2} \mathrm{O}_{2}$ in leaves was detected by 3,3-diaminobenzidine (DAB) staining and micro hydrogen peroxide $\left(\mathrm{H}_{2} \mathrm{O}_{2}\right)$ assay kit (Solarbio, Beijing, China). The yeast two-hybrid results showed that DoCDPK9-1 and DoCDPK20-4 interacted with RbohD and $\mathrm{RbohH}$, respectively. In addition, no $\mathrm{H}_{2} \mathrm{O}_{2}$ content was accumulated in the control, whereas hormone treatments resulted in $\mathrm{H}_{2} \mathrm{O}_{2}$ accumulation in the leaves of plants, with peak levels at 3 and $1 \mathrm{~h}$ after the spraying with SA and JA, respectively. Scanning electron microscopy analyses of stomata revealed that the stomatal apertures were larger after treatments with SA and JA, followed by a gradual decrease and finally closure at $3 \mathrm{~h}$ after hormone treatments. 
DoCDPK6-1 DoCDPK6-3 DoCDPK11-1 DoCDPK11-2 DoCDPK20-1 DoCDPK20-4 DoCDPK20-3 DoCDPK20-2 DoCDPK34 DoCDPK3-2 DoCDPK3-1 DoCDPK29 DoCDPK9-2 DoCDPK9DoCDPK24 DoCDPK13-1 DoCDPK13-2 DoCDPK 7 DoCDPK8-1 DoCDPK28-1 DoCDPK16 DoCDPK28-2
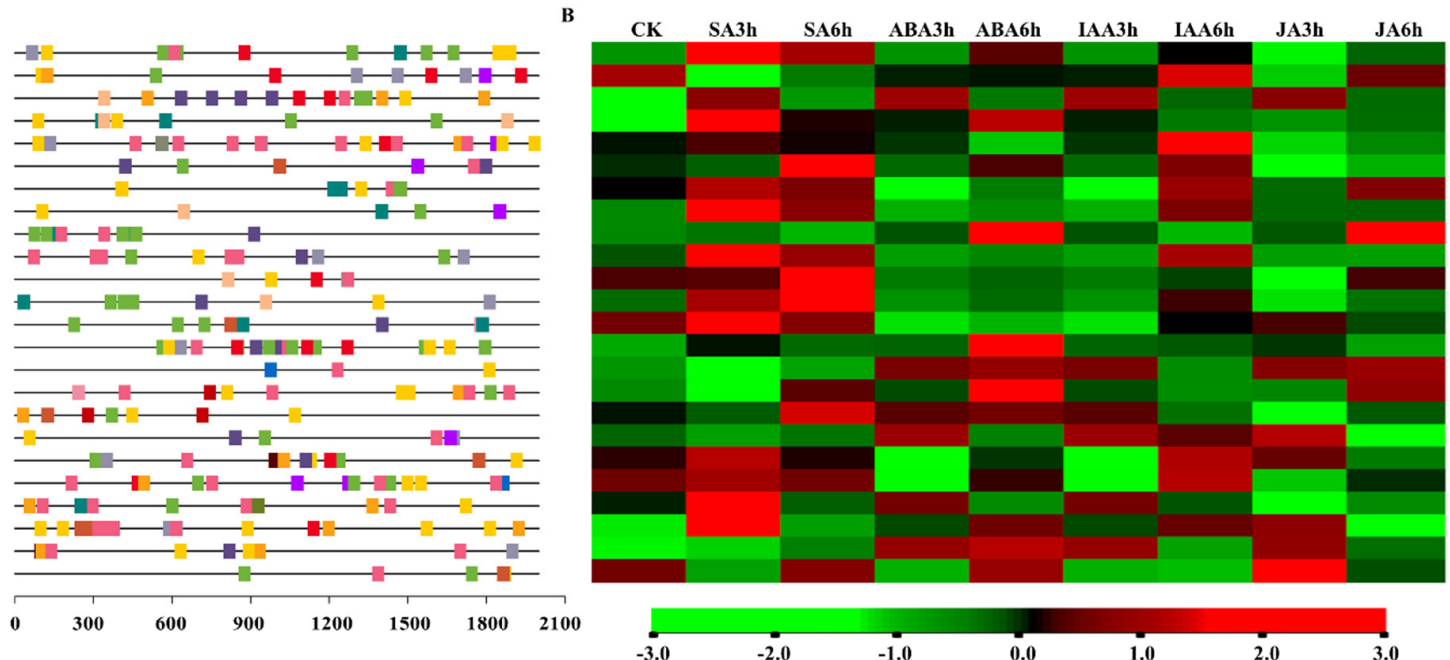

Symbol Element Consensus

invoved in the abscisic acid responsiveness

Essential for the anaerobic induction

- Invoved in MeJA-responsiveness

- Invored in defare and

Invoved in defense and stres

Auxin- besponsive element

in drought-inducibility

Involved in salicylic acid responsiveness

Involved in low-temperature responsivenes

Gibberellin responsive element

Symbol Element Consensus

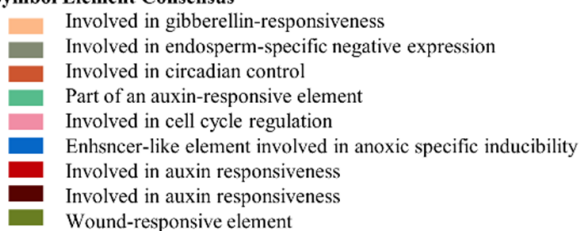

Figure 4. Distribution of cis-acting elements related to stress responsiveness, plant growth, and development. (A) Distribution of cis-acting elements on CDPK upstream, represented by rectangles of different colors. (B) CDPK gene expression profiles in D. officinale in response to CK (untreated leaves), SA (salicylic acid, $10 \mu \mathrm{M}$ ), ABA (abscisic acid, $0.2 \mu \mathrm{M}$ ), auxin (IAA, $2 \mu \mathrm{M}$ ), and JA (jasmonic acid, $10 \mu \mathrm{M})$. Data for the transcript levels of DoCDPKs with different hormone treatment using the FPKMs (fragments per kilobase of exon model per million mapped fragments) value that downloaded from the Biodiversity Data Center (iflora.cn (accessed on 12 September 2021)). A heatmap was generated using the Genesis software. Parameters were set as log 10 transformation, and genes were normalized. High, moderate, and low expression levels of one gene were shown in red, black, and green, respectively, with different treatments.

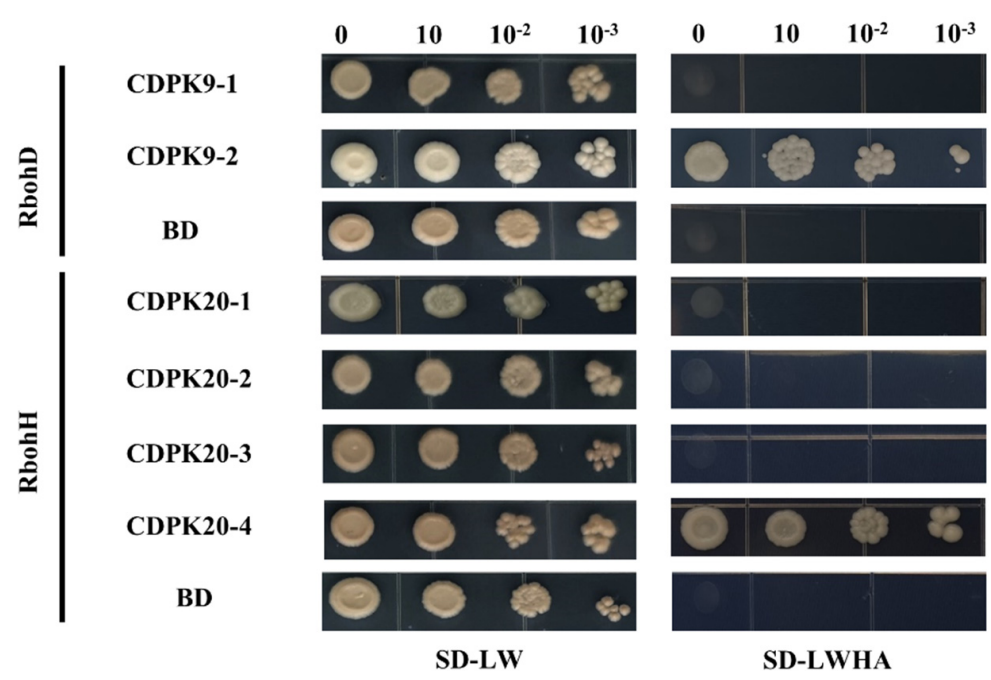

Figure 5. Yeast two-hybrid analysis of the interaction between certain CDPK and Rboh proteins in $D$. officinale. The yeast cells of strain AH109, containing the target plasmid combinations, were grown on a nonselected SD-leucine-tryptophan (SD-LW) or selective SD-leucine-tryptophan-histidine-adenine (SD-LWHA) media. BD is the empty PGBDT7 vector. Here, $0,10^{-1}, 10^{-2}$, and $10^{-3}$ represent the dilution multiples of the bacterial solution. 
A

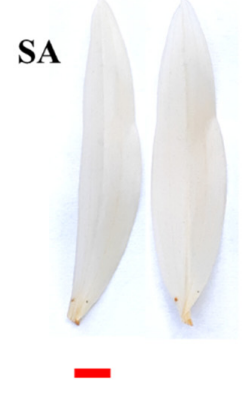

JA

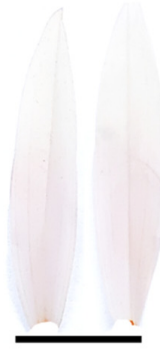

oh
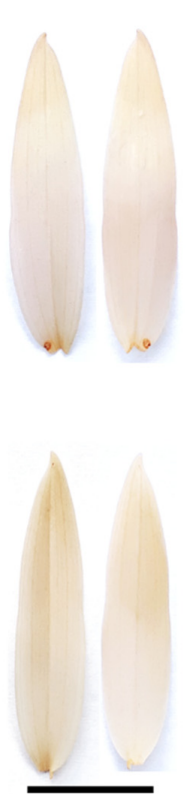

$0.5 h$

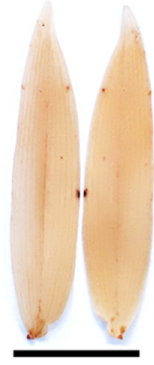

1h
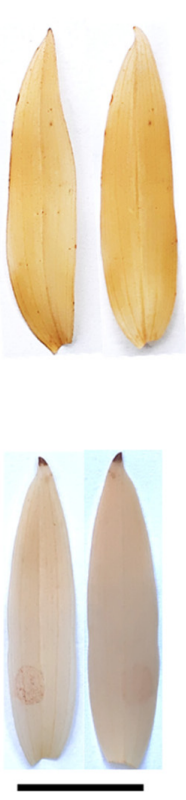

3h

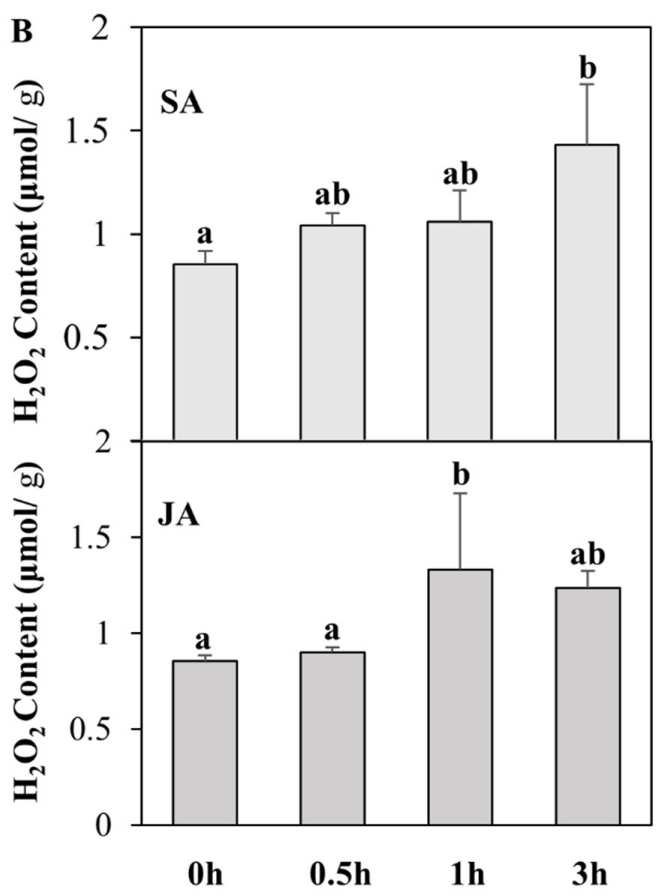

C

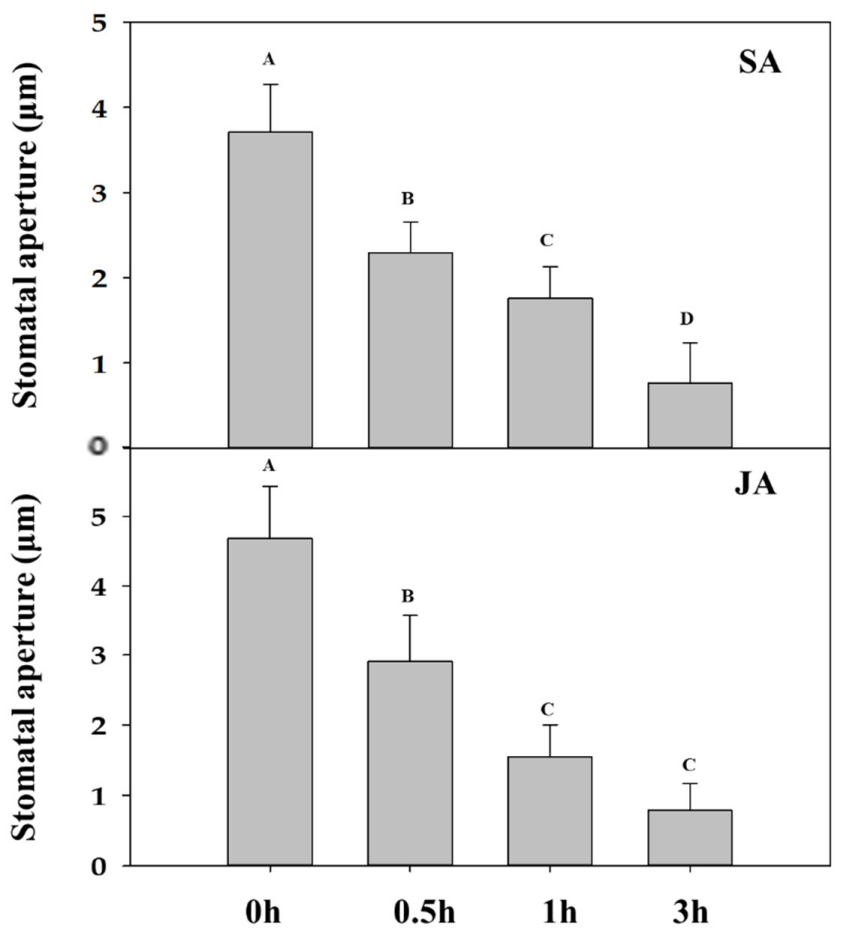

D
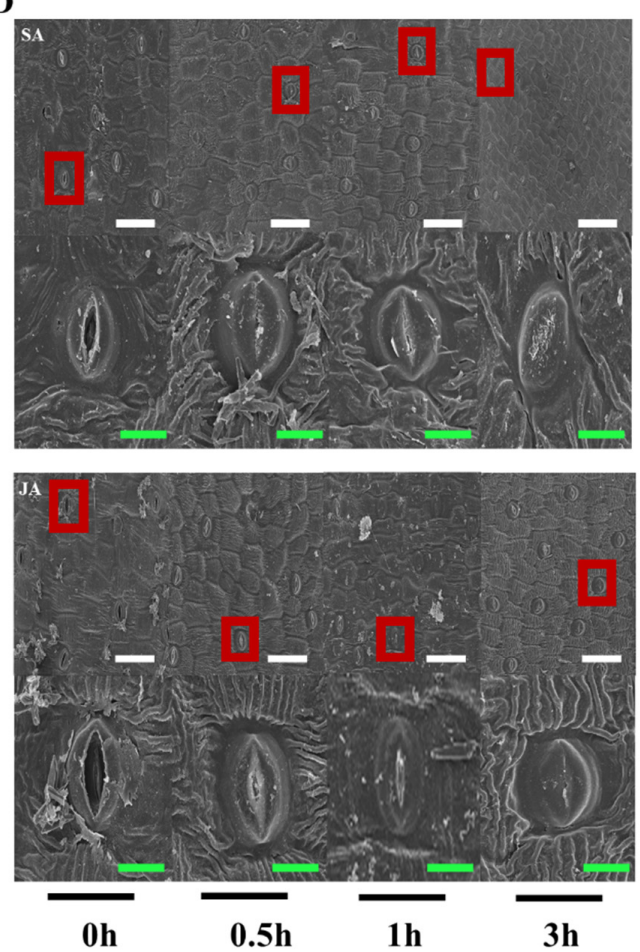

Figure 6. $\mathrm{H}_{2} \mathrm{O}_{2}$ content and changes in stomata aperture in response to treatment with salicylic acid (SA, $10 \mu \mathrm{M}$ ) and JA (jasmonic acid, $10 \mu \mathrm{M}$ ). (A) $\mathrm{H}_{2} \mathrm{O}_{2}$ staining with DAB (3,3-diaminobenzidine) in SA/JA treatments. The red bar in the upper image means $0.5 \mathrm{~cm}$. (B) $\mathrm{H}_{2} \mathrm{O}_{2}$ content in leaves of plants treated with SA/JA. Means denoted by different letters are significant $(p<0.05)$. (C) Effect of SA/JA treatment on the stomatal aperture of D. officinale. Five leaves in the same general location were used to record stomatal aperture, and 15 stomata were observed for each sample. Date were analyzed by SigmaPlot. Means denoted by different letters are significant $(p<0.01)$. (D) Phenotype of stomatal aperture. Data were collected from three independent experiments. The white bar in the upper images means $100 \mu \mathrm{m}$. The figure shown below is an enlargement of that in upper red box. The green bar in the images means $30 \mu \mathrm{m}$. 


\section{Discussion}

The number of $C D P K$ genes varies widely among different plant species. Diploid plants such as $A$. thaliana, rice, and soybean have 34,29 , and $50 C D P K$ genes, respectively $[5,37,38]$. Here, we identified 24 CDPK genes and designated them as DoCDPKs. Similar to CDPKs in other species, DoCDPKs form four groups, as confirmed by the phylogenetic study (Figure 1). Groups 1 and 2 of D. officinale CDPKs had 9 and 6 members, respectively, compared with 10 and 13 in A. thaliana; 11 and 8 in rice; and 17 and 15 in soybean. This was consistent with the observation in other species, the number of CDPKs largely depends on the number of genes in groups 1 and 2 [38]. Moreover, studies on CDPK genes in rice revealed a greater probability of intron loss than intron gain $[39,40]$. Similar to the genetic structure of CDPKs in populus, grape, and maize, DoCDPKs in group 1 had 6-9 introns, and those in group 4 had the highest number of introns [21,41,42]. Therefore, we assumed that $C D P K$ genes in group 4 were more ancient than those in other groups. Motif prediction analyses revealed more gene motifs in groups 1-3 than in group 4; the number of motifs among the four groups varied. Thus, we hypothesized that DoCDPKs have evolved diverse functions, with genes in the same group having similar functions and those in different groups having different functions. This pattern of functional diversity has also been detected for the CDPKs of pepper, rice, and maize [20,43,44]. Altogether, these results suggest that gene function exerts a feedback effect on the copy number of genes in a family [45].

Gene duplication has been observed in flies as early as 1963 [46]. Subsequent studies reported that it played a crucial role in the adaptation of species to the environment [47]. Species evolution can be detected using the Ks/Ka ratio [48]. We calculated this index for homologous gene pairs to explore the selection of DoCDPKs. Similar to the CDPKs in turnip and cucumber, those in D. officinale displayed a low Ka/Ks ratio (less than 1, Table 2), indicating that DoCDPKs had undergone negative selection [49,50]. The Ks values differed among gene pairs, indicating the evolution rate varied in homologous genes which could result in functional diversification. CDPKs are known to regulate diverse biological processes, including responses to hormones [51-55]. In several plant species, CDPK transcript levels changed with hormone treatments, including JA and SA [56-58]. The majority of DoCDPKs in our study were upregulated following the SA/JA treatment (Figure 4B), whereas homologous genes showed varied expressions, indicating functional divergence among CDPKs. This finding is consistent with the CDPK expression profiles in grapevine and DcSDG gene in Dendrobium catenatum, suggesting functional divergence in paralogs $[19,59]$. Further study of cis-acting elements (Figure $4 \mathrm{~A}$ ) revealed differences between homologous genes in terms of the presence of stress-responsive elements and elements involved in the regulation of growth and development in their promoter regions. These findings indicated a functional divergence of DoCDPKs.

The interaction between $C D P K$ and Rboh regulates the rapid generation of ROS in response to stress stimuli in plants [60,61]. In potatoes, StCDPK5 interacts with StRbohC to increase pathogen resistance via ROS burst [29]. Here, we found that DoCDPK 9-2 and DoCDPK 20-4 interacted with Rboh D and Rboh H separately (Figure 5); however, their homologous gene DoCDPK9-1 and DoCDPK20-1/-2/-3 did not interact with Rbohs. These results, in combination with the upregulated expression of homologous gene pairs CDPK9-1/-2 and CDPK20-1/-2/-3/-4 following JA/SA treatments, suggested a different role of homologous gene pairs in SA/JA-induced ROS accumulation, indicating that the function of CDPK9-1/-2 and CDPK 20-1/-2/-3/-4 was differentiated. AtCDPK1 interacted with AtRbohD to regulate Rboh-mediated ROS generation and protect $A$. thaliana from DC3000 [62]. Here, we found that $\mathrm{H}_{2} \mathrm{O}_{2}$ content increased in hormone-treated leaves (Figure 6A,B), and the stomata closed gradually (Figure 6C,D). The timely closure of the stomata protects plants from pathogens and pests [63]. Our further study found the stomal aperture decreased following hormone treatments (Figure 6C,D). These findings suggest that interactions of DoCDPKs and DoRbohs in JA/SA induced stomatal closure via the $\mathrm{H}_{2} \mathrm{O}_{2}$ pathway. This finding is consistent with the result that the overexpression 
of $V p C D P K 9$ enhanced the grapevine resistance to powdery mildew due to the increased production of $\mathrm{SA}$ and excess accumulation of $\mathrm{H}_{2} \mathrm{O}_{2}$ in the epidermal cells. Similarly, the expression of stress-responsive genes, including AtRboh, was increased in the CsCDPK20 transgentic A. thaliana $[64,65]$.

\section{Methods}

\subsection{Identification of Members of CDPK Gene Family in D. officinale}

Genomic sequences were obtained from the website (Index of/genomes/all/GCF/001/ 605/985/GCF_001605985.2_ASM160598v2 (nih.gov) (accessed on 5 August 2021)). Proteins containing PF00069 (protein kinase domain) and PF13499 (EF-hand calcium-binding domains) [42] were identified from the D. officinale genome using a Simple HMM Search in TBtools. The number of EF-hand domains was predicted by SMART (embl-heidelberg.de (accessed on 15 August 2021)) [66], the molecular weight, theoretical isoelectric point, grand average of hydropathicity, and myristoylation sites were predicted using ExPASy (https: / / web.expasy.org (accessed on 21 August 2021)), and palmitoylation and N-terminal acetylation were detected using CCS-Palm 4.0 GSP-PAIL 2.0 (biocuckoo.org (accessed on 21 August 2021)) [67,68].

\subsection{Phylogenetic and Gene Structure Analyses}

The $A$. thaliana CDPK genes sequences were downloaded from The Arabidopsis Information Resource (TAIR, arabidopsis.org (accessed on 5 August 2021)). Both D. officinale and $A$. thaliana CDPK protein sequences were aligned using MAFFT 7.0. Next, MEGAX version 7.0 was used to construct a phylogenetic tree using the neighbor-joining (NJ) method [69]. Gene exon/intron structures were analyzed using tools available at the Gene Structure Display Server (gao-lab.org (accessed on 21 August 2021)) [70].

\subsection{Evolutionary and Conserved Motif Analyses}

Gene pairs with close genetic relationships were identified, and the synonymous (Ks) and nonsynonymous (Ka) substitution rates were calculated using TBtools. The amino acid sequence identity between each pair of DoCDPK proteins was calculated using the DNAMAN software. The conserved motifs of DoCDPKs were predicted using tools available at MEME (meme-suite.org (accessed on 14 November 2021)).

\subsection{Cis-Acting Element Prediction and Analyses of Gene Expression}

Data for the transcript levels of DoCDPK genes in ten tissues including the flower, sepal, labellum, pollinium, gynostemium, stem, leaf, root, green root tip (root tip), and white part of the root (part root), and treatments with different hormones (foliar sprayed with $10 \mu \mathrm{M} \mathrm{SA}, 0.2 \mu \mathrm{M}$ ABA, $2 \mu \mathrm{M}$ IAA, and $10 \mu \mathrm{M}$ JA) were downloaded from OrchidBase (ncku.edu.tw (accessed on 12 September 2021)) and Biodiversity Data Center (iflora.cn (accessed on 15 September 2021)), respectively [71]. A heatmap was constructed using the Genesis software [72]. Sequences 2000 base pair upstream of the coding sequences of DoCDPKs were extracted using TBtools and submitted to PlantCare (ugent.be (accessed on 17 September)) to predict cis-acting elements.

\subsection{RNA Extraction and Analysis of Quantitative Real-Time PCR}

The total RNA of untreated 6 month-old catenatum leaves (CK) and leaves sprayed with $10 \mu \mathrm{M}$ SA, $0.2 \mu \mathrm{M}$ ABA, $2 \mu \mathrm{M}$ IAA, and $10 \mu \mathrm{M}$ JA at 3 and $6 \mathrm{~h}$ were isolated using method described by Ksenija Gassic [73]. The RNA quality was determined using NanoDrop 1000 spectrophotometer (NanoDrop Technologies, Wilmington, DE, USA). Afterward, $0.5 \mu \mathrm{g}$ of RNA was used for first-strand complementary DNA (cDNA) synthesis by Superscript III reverse transcriptase (Invitrogen, Waltham, MA, USA), following the manufacturer's instructions. Primers for q-PCR (Table S2) were designed using PrimerBLAST (Primer designing tool (nih.gov) (accessed on 14 November 2021)), offering the following parameters: 100-200 base pair of PCR product size, Refseq mRNA database, 
57-63 ${ }^{\circ} \mathrm{C}$ primer melting temperatures, and Dendrobium catenatum (TaxID: 906689) for "Organism". Each sample included three biological and technical replicates. PCR reactions were performed under the following conditions: 40 cycles of $5 \mathrm{~s}$ at $95^{\circ} \mathrm{C}, 15 \mathrm{~s}$ at $60{ }^{\circ} \mathrm{C}$, and $34 \mathrm{~s}$ at $72{ }^{\circ} \mathrm{C}$ using FastStart Universal SYBR Green Master (Rox, Roche, Indianapolis, IN, USA).

\subsection{Yeast Two-Hybrid Analyses}

The full-length coding sequences of DoCDPK9-1/9-2/20-1/20-2/20-3/20-4 were subcloned into the PGBKT7(BD) vector (Generay Biotech Co. Ltd., Shanghai, China). Three Rbohs, named DoRboh D/F/H, were obtained from D. officinale with the $A$. thaliana Rboh as the query and subcloned into the PGADT7(AD) vector (Generay Biotech Co. Ltd., Shanghai, China). The primers are shown in Table S3. The transformed plasmids harboring CDPK and Rboh sequences were introduced into the yeast strains Y2H and Y187, respectively. After being plated on two kinds of media, that nonselective media (SD-leucine-tryptophan) and selective media (SD-leucine-tryptophan-histidine and SD-leucine-tryptophan-histidineadenine), were performed according to the method described by Wang [45].

\subsection{Determination of Hydrogen Peroxide Content and Stomatal Aperture in Leaves}

Dendrobium officinale was cultivated in a 5:1 (w/w) soil: sand mixture in a greenhouse at $24{ }^{\circ} \mathrm{C}$ with $60-80 \%$ relative humidity and $16 \mathrm{~h}$ of photoperiod (daytime, 06:00-20:00). Six month-old catenatum leaves were sprayed with $10 \mu \mathrm{M}$ SA or JA separately and sampled at $0,0.5,1$, and $3 \mathrm{~h}$ after the treatment; $0 \mathrm{~h}$ was set as the control, according to the method described by Zhang [74]. Leaf samples were soaked in 3,3-diaminobenzidine $(\mathrm{DAB}, 1 \mathrm{mg} / \mathrm{mL}, \mathrm{PH} 3.8)$ for $8 \mathrm{~h}$, and pigments were removed using boiling alcohol before observing the DAB staining pattern. The $\mathrm{H}_{2} \mathrm{O}_{2}$ content was measured following the manufacturer's instructions using the $\mathrm{H}_{2} \mathrm{O}_{2}$ assay kit (Solarbio, China). Other leaf samples were observed from stomata, and the stomatal aperture was measured under a scanning electron microscope using the method described by Yang [75]. Fresh leaves were fixed with $1 \% v / v$ glutaraldehyde for at least $24 \mathrm{~h}$ at $4{ }^{\circ} \mathrm{C}$ and subsequently substituted with a series gradient concentration of alcohol $(50 \%, 70 \%, 85 \%, 95 \%$, and $100 \%)$, each for $1 \mathrm{~h}$ before being subjected to critical-point-drying using liquid carbon dioxide and coated with gold and palladium. Five leaves in the same general location were used to observe the stoma per treatment under a scanning electron microscope. Fifteen stomata were measured for each sample.

\section{Conclusions}

As one of the crucial signal molecules in the plant stress response, members of CDPK family have been studied in several species. Although no study has been reported in $D$. officinale, we identified members of the CDPK gene family in D. officinale and explored their functions in response to SA and JA stress. We identified 24 members in the D. officinale $C D P K$ gene family. The differences in their evolution rates and expression profiles were indicative of functional divergence. Among them, DoCDPK 9-2, and DoCDPK 20-4 were upregulated by SA or JA treatment. In addition, they interacted with $\mathrm{Rboh} D / \mathrm{H}$ to decrease the stomatal aperture by regulating the accumulation of $\mathrm{H}_{2} \mathrm{O}_{2}$ in the leaves in response to stress.

Supplementary Materials: The following supporting information can be downloaded at: https: / /www.mdpi.com/article/10.3390/ijms23031298/s1.

Author Contributions: Y.Y. (Yongping Yang) and Y.Y. (Yunqiang Yang) designed the experiments. X.Y. (Xingyu Yang), Z.C. and X.Y. (Xin Yin) performed the experiments. X.Y. (Xingyu Yang) and Z.C. analyzed the data and wrote the paper. Y.Y. (Yongping Yang) and Y.W. revised the manuscript. All authors have read and agreed to the published version of the manuscript.

Funding: This research was funded by grants from the Beijing DR PLANT Biotechnology Co., Ltd. (2019H078), the National Natural Science Foundation of China (grant number 41771123 and 32070362), 
the Postdoctoral Research Funding Projects of Yunnan Province (to Xin Yin), the Yunnan Fundamental Research Projects (grant number 202101AT070190), Digitalization, Development and Application of Biotic Resource (grant number 202002AA100007), poverty alleviation through science and technology projects of Chinese Academy of Sciences (grant number KFJ-FP-201905), and technology transfer into Yunnan project (grant number 202003AD150005), the Project of Science and Technology of Guizhou Province (NY [2017] 2524).

Institutional Review Board Statement: Not applicable.

Informed Consent Statement: Not applicable.

Data Availability Statement: Not applicable.

Conflicts of Interest: The authors declare no conflict of interest. The funders had no role in the design of the study; in the collection, analyses, or interpretation of data; in the writing of the manuscript, or in the decision to publish the results.

\section{References}

1. Xiong, L.; Schumaker, K.S.; Zhu, J.K. Cell signaling during cold, drought, and salt stress. Plant Cell 2002, 14 (Suppl. 1), S165-S183. [CrossRef] [PubMed]

2. Hetherington, A.M.; Brownlee, C. The generation of $\mathrm{Ca}(2+)$ signals in plants. Annu. Rev. Plant Biol. 2004, 55, 401-427. [CrossRef] [PubMed]

3. McCormack, E.; Braam, J. Calmodulins and related potential calcium sensors of Arabidopsis. New Phytol. 2003, 159, 585-598 [CrossRef] [PubMed]

4. Kolukisaoglu, U.; Weinl, S.; Blazevic, D.; Batistic, O.; Kudla, J. Calcium sensors and their interacting protein kinases: Genomics of the Arabidopsis and rice CBL-CIPK signaling networks. Plant Physiol. 2004, 134, 43-58. [CrossRef] [PubMed]

5. $\quad$ Cheng, S.H.; Willmann, M.R.; Chen, H.C.; Sheen, J. Calcium signaling through protein kinases. The Arabidopsis calciumdependent protein kinase gene family. Plant Physiol. 2002, 129, 469-485. [CrossRef] [PubMed]

6. Zielinski, R.E. Calmodulin and calmondulin-binding proteins in plants. Annu. Rev. Plant Physiol. 1998, 49, 697-725. [CrossRef] [PubMed]

7. Roberts, D.M. Calcium-modulated proteins: Targets of interacellular calcium signals in higher plants. Plant Physiol. 1992, 43, 375-414. [CrossRef]

8. Sanders, D.; Pelloux, J.; Brownlee, C.; Harper, J.F. Calcium at the crossroads of signaling. Plant Cell 2002, 14, S401-S417. [CrossRef]

9. Yip Delormel, T.; Boudsocq, M. Properties and functions of calcium-dependent protein kinases and their relatives in Arabidopsis thaliana. New Phytol. 2019, 224, 585-604. [CrossRef]

10. Simeunovic, A.; Mair, A.; Wurzinger, B.; Teige, M. Know where your clients are: Subcellular localization and targets of calciumdependent protein kinases. J. Exp. Bot. 2016, 67, 3855-3872. [CrossRef]

11. Wernimont, A.K.; Artz, J.D.; Finerty, P., Jr.; Lin, Y.H.; Amani, M.; Allali-Hassani, A.; Senisterra, G.; Vedadi, M.; Tempel, W.; Mackenzie, F.; et al. Structures of apicomplexan calcium-dependent protein kinases reveal mechanism of activation by calcium. Nat. Struct. Mol. Biol. 2010, 17, 596-601. [CrossRef] [PubMed]

12. Harper, J.F.; Sussman, M.R.; Schaller, G.E.; Putnam-Evans, C.; Charbonneau, H.; Harmon, A.C. A calcium-dependent protein kinase with a regulatory domain similar to calmodulin. Science 1991, 252, 951-954. [CrossRef] [PubMed]

13. Harmon, A.C.; Gribskov, M.; Gubrium, E.; Harper, J.F. The CDPK superfamily of protein kinases. New Phytol. 2001, 151, 175-183. [CrossRef] [PubMed]

14. Harmon, A.C. Calcium-regulated protein kinases of plants. Gravit. Space Biol. Bull. 2003, 16, 83-90.

15. Harper, J.F.; Breton, G.; Harmon, A. Decoding Ca(2+) signals through plant protein kinases. Annu. Rev. Plant Biol. 2004, 55, 263-288. [CrossRef]

16. Hegeman, A.D.; Rodriguez, M.; Han, B.W.; Uno, Y.; Phillips, G.N., Jr.; Hrabak, E.M.; Cushman, J.C.; Harper, J.F.; Harmon, A.C.; Sussman, M.R. A phyloproteomic characterization of in vitro autophosphorylation in calcium-dependent protein kinases. Proteomics 2006, 6, 3649-3664. [CrossRef]

17. Hrabak, E.M.; Chan, C.W.; Gribskov, M.; Harper, J.F.; Choi, J.H.; Halford, N.; Kudla, J.; Luan, S.; Nimmo, H.G.; Sussman, M.R.; et al. The Arabidopsis CDPK-SnRK superfamily of protein kinases. Plant Physiol. 2003, 132, 666-680. [CrossRef]

18. Yang, Y.; Wang, Q.; Chen, Q.; Yin, X.; Qian, M.; Sun, X.; Yang, Y. Genome-wide survey indicates diverse physiological roles of the barley (Hordeum vulgare L.) calcium-dependent protein kinase genes. Sci. Rep. 2017, 7, 5306. [CrossRef]

19. Chen, F.; Fasoli, M.; Tornielli, G.B.; Dal Santo, S.; Pezzotti, M.; Zhang, L.; Cai, B.; Cheng, Z.M. The evolutionary history and diverse physiological roles of the grapevine calcium-dependent protein kinase gene family. PLoS ONE 2013, 8, e80818. [CrossRef]

20. Cai, H.; Cheng, J.; Yan, Y.; Xiao, Z.; Li, J.; Mou, S.; Qiu, A.; Lai, Y.; Guan, D.; He, S. Genome-wide identification and expression analysis of calcium-dependent protein kinase and its closely related kinase genes in Capsicum annuum. Front. Plant Sci. 2015, 6, 737. [CrossRef]

21. Kong, X.; Lv, W.; Jiang, S.; Zhang, D.; Cai, G.; Pan, J.; Li, D. Genome-wide identification and expression analysis of calciumdependent protein kinase in maize. BMC Genom. 2013, 14, 433. [CrossRef] [PubMed] 
22. Liu, W.; Li, W.; He, Q.; Daud, M.K.; Chen, J.; Zhu, S. Genome-wide survey and expression analysis of calcium-dependent protein kinase in Gossypium raimondii. PLoS ONE 2014, 9, e98189. [CrossRef] [PubMed]

23. Shkryl, Y.N.; Veremeichik, G.N.; Silantieva, S.A.; Bulgakov, V.P. Differential expression of calcium-dependent protein kinase genes (CDPK1-14) in Rubia cordifolia callus cultures transformed with the rolB and rolC genes. Plant Gene 2020, 21, 100215. [CrossRef]

24. Romeis, T.; Ludwig, A.A.; Martin, R.; Jones, J.D.G. Calcium-dependent protein kinases play an essential role in a plant defence response. EMBO J. 2001, 20, 5556-5567. [CrossRef] [PubMed]

25. Franz, S.; Ehlert, B.; Liese, A.; Kurth, J.; Cazale, A.C.; Romeis, T. Calcium-dependent protein kinase CPK21 functions in abiotic stress response in Arabidopsis thaliana. Mol. Plant 2011, 4, 83-96. [CrossRef] [PubMed]

26. Ishida, S.; Yuasa, T.; Nakata, M.; Takahashi, Y. A tobacco calcium-dependent protein kinase, CDPK1, regulates the transcription factor REPRESSION OF SHOOT GROWTH in response to gibberellins. Plant Cell 2008, 20, 3273-3288. [CrossRef]

27. Crizel, R.L.; Perin, E.C.; Vighi, I.L.; Woloski, R.; Seixas, A.; da Silva Pinto, L.; Rombaldi, C.V.; Galli, V. Genome-wide identification, and characterization of the CDPK gene family reveal their involvement in abiotic stress response in Fragaria xananassa. Sci. Rep. 2020, 10, 11040. [CrossRef]

28. Yamauchi, T.; Yoshioka, M.; Fukazawa, A.; Mori, H.; Nishizawa, N.K.; Tsutsumi, N.; Yoshioka, H.; Nakazono, M. An NADPH oxidase $\mathrm{RBOH}$ functions in rice roots during lysigenous aerenchyma formation under oxygen-deficient conditions. Plant Cell 2017, 29, 775-790. [CrossRef]

29. Kobayashi, M.; Ohura, I.; Kawakita, K.; Yokota, N.; Fujiwara, M.; Shimamoto, K.; Doke, N.; Yoshioka, H. Calcium-dependent protein kinases regulate the production of reactive oxygen species by potato NADPH oxidase. Plant Cell 2007, 19, 1065-1080. [CrossRef]

30. Ng, T.B.; Liu, J.; Wong, J.H.; Ye, X.; Wing Sze, S.C.; Tong, Y.; Zhang, K.Y. Review of research on Dendrobium, a prized folk medicine. Appl. Microbiol. Biotechnol. 2012, 93, 1795-1803. [CrossRef]

31. Pan, L.H.; Li, X.F.; Wang, M.N.; Zha, X.Q.; Yang, X.F.; Liu, Z.J.; Luo, Y.B.; Luo, J.P. Comparison of hypoglycemic and antioxidative effects of polysaccharides from four different Dendrobium species. Int. J. Biol. Macromol. 2014, 64, 420-427. [CrossRef] [PubMed]

32. Tang, H.; Zhao, T.; Sheng, Y.; Zheng, T.; Fu, L.; Zhang, Y. Dendrobium officinale Kimura et Migo: A review on its ethnopharmacology, phytochemistry, pharmacology, and industrialization. Evid. Based Complement. Altern. Med. 2017, 2017, 7436259. [CrossRef] [PubMed]

33. Dressler, R.L. Phylogeny and Classification of Orchid Family; Dioscorides Press: Hong Kong, China, 1993.

34. Yan, L.; Wang, X.; Liu, H.; Tian, Y.; Lian, J.; Yang, R.; Hao, S.; Wang, X.; Yang, S.; Li, Q.; et al. The genome of Dendrobium officinale illuminates the biology of the important traditional Chinese Orchid herb. Mol. Plant 2015, 8, 922-934. [CrossRef] [PubMed]

35. Si, J.P.; Wang, Q.; Liu, Z.J.; Liu, J.J.; Luo, Y.B. Breakthrough in key science and technologies in Dendrobium catenatum industry. Zhongguo Zhong Yao Za Zhi 2017, 42, 2223-2227. [CrossRef]

36. Chen, C.; Chen, H.; Zhang, Y.; Thomas, H.R.; Frank, M.H.; He, Y.; Xia, R. TBtools: An integrative toolkit developed for interactive analyses of big biological data. Mol. Plant 2020, 13, 1194-1202. [CrossRef]

37. Hettenhausen, C.; Sun, G.; He, Y.; Zhuang, H.; Sun, T.; Qi, J.; Wu, J. Genome-wide identification of calcium-dependent protein kinases in soybean and analyses of their transcriptional responses to insect herbivory and drought stress. Sci. Rep. 2016, 6, 18973. [CrossRef]

38. Asano, T.; Tanaka, N.; Yang, G.; Hayashi, N.; Komatsu, S. Genome-wide identification of the rice calcium-dependent protein kinase and its closely related kinase gene families: Comprehensive analysis of the CDPKs gene family in rice. Plant Cell Physiol. 2005, 46, 356-366. [CrossRef]

39. Roy, S.W.; Penny, D. Patterns of intron loss and gain in plants: Intron loss-dominated evolution and genome-wide comparison of O. sativa and A. thaliana. Mol. Biol. Evol. 2007, 24, 171-181. [CrossRef]

40. Lin, H.; Zhu, W.; Silva, J.C.; Gu, X.; Buell, C.R. Intron gain and loss in segmentally duplicated genes in rice. Genome Biol. 2006, 7, R41. [CrossRef]

41. Zuo, R.; Hu, R.; Chai, G.; Xu, M.; Qi, G.; Kong, Y.; Zhou, G. Genome-wide identification, classification, and expression analysis of CDPK and its closely related gene families in poplar (Populus trichocarpa). Mol. Biol. Rep. 2013, 40, 2645-2662. [CrossRef]

42. Zhang, K.; Han, Y.T.; Zhao, F.L.; Hu, Y.; Gao, Y.R.; Ma, Y.F.; Zheng, Y.; Wang, Y.J.; Wen, Y.Q. Genome-wide identification and expression analysis of the CDPK gene family in Grape, Vitis spp. BMC Plant Biol. 2015, 15, 1-19. [CrossRef] [PubMed]

43. Ye, S.; Wang, L.; Xie, W.; Wan, B.; Li, X.; Lin, Y. Expression profile of calcium-dependent protein kinase (CDPKs) genes during the whole lifespan and under phytohormone treatment conditions in rice (Oryza sativa L. ssp. indica). Plant Mol. Biol. 2009, 70, 311-325. [CrossRef] [PubMed]

44. Ma, P.; Liu, J.; Yang, X.; Ma, R. Genome-wide identification of the maize calcium-dependent protein kinase gene family. Appl. Biochem. Biotechnol. 2013, 169, 2111-2125. [CrossRef] [PubMed]

45. Cannon, S.B.; Mitra, A.; Baumgarten, A.; Young, N.D.; May, G. The roles of segmental and tandem gene duplication in the evolution of large gene families in Arabidopsis thaliana. BMC Plant Biol. 2004, 4, 1-21. [CrossRef] [PubMed]

46. Bridge, S.B. The bar "gene" a duplication. Science 1936, 83, 210-211. [CrossRef]

47. Kondrashov, F.A. Gene duplication as a mechanism of genomic adaptation to a changing environment. Proc. Biol. Sci. 2012, 279, 5048-5057. [CrossRef]

48. Yang, X.; Tuskan, G.A.; Cheng, M.Z. Divergence of the Dof gene families in poplar, Arabidopsis, and rice suggests multiple modes of gene evolution after duplication. Plant Physiol. 2006, 142, 820-830. [CrossRef] 
49. Wang, Q.; Yin, X.; Chen, Q.; Xiang, N.; Sun, X.; Yang, Y.; Yang, Y. Genome-wide survey indicates diverse physiological roles of the turnip (Brassica rapa var. rapa) calcium-dependent protein kinase genes. Sci. Rep. 2017, 7, 1-14. [CrossRef]

50. Xu, X.; Liu, M.; Lu, L.; He, M.; Qu, W.; Xu, Q.; Qi, X.; Chen, X. Genome-wide analysis and expression of the calcium-dependent protein kinase gene family in cucumber. Mol. Genet. Genomics. 2015, 290, 1403-1414. [CrossRef]

51. Klimecka, M.; Muszyńska, G. Structure and functions of plant calcium-dependent protein kinases. Acta Biochim. 2007, 54, 219-233. [CrossRef]

52. Ludwig, A.A.; Romeis, T.; Jones, J.D. CDPK-mediated signalling pathways: Specificity and cross-talk. J. Exp. Bot. 2004, 55, 181-188. [CrossRef] [PubMed]

53. Tena, G.; Boudsocq, M.; Sheen, J. Protein kinase signaling networks in plant innate immunity. Curr. Opin. Plant Biol. 2011, 14, 519-529. [CrossRef] [PubMed]

54. Harper, J.F.; Harmon, A. Plants, symbiosis and parasites: A calcium signalling connection. Nat. Rev. Mol. Cell Biol. 2005, 6, 555-566. [CrossRef] [PubMed]

55. Zhang, H. Identification, expression and interaction analyses of calcium-dependent protein kinase (CPK) genes in canola (Brassica napus L.). BMC Genom. 2014, 15, 1-17. [CrossRef]

56. Li, A.; Wang, X.; Leseberg, C.H.; Jia, J.; Mao, L. Biotic and abiotic stress responses through calcium-dependent protein kinase (CDPK) signaling in wheat (Triticum aestivum L.). Plant Signal. Behav. 2008, 3, 654-656. [CrossRef]

57. Matschi, S.; Hake, K.; Herde, M.; Hause, B.; Romeis, T. The calcium-dependent protein kinase CPK28 regulates development by inducing growth phase-specific, spatially restricted alterations in jasmonic acid levels independent of defense responses in Arabidopsis. Plant Cell 2015, 27, 591-606. [CrossRef]

58. Fu, L.; Yu, X.; An, C. Overexpression of constitutively active OsCPK10 increases Arabidopsis resistance against pseudomonas syringae pv. tomato and rice resistance against magnaporthe grisea. Plant Physiol. Biochem. 2013, 73, 202-210. [CrossRef]

59. Chen, D.H.; Qiu, H.L.; Huang, Y.; Zhang, L.; Si, J.P. Genome-wide identification and expression profiling of SET doman group family in Dendrobium catenatum. BMC Plant Biol. 2020, 20, 40. [CrossRef]

60. Dubiella, U.; Seybold, H.; Durian, G.; Komander, E.; Lassig, R.; Witte, C.P.; Schulze, W.X.; Romeis, T. Calcium-dependent protein kinase/NADPH oxidase activation circuit is required for rapid defense signal propagation. Proc. Natl. Acad. Sci. USA 2013, 110, 8744-8749. [CrossRef]

61. Yu, H.; Xiao, A.; Dong, R.; Fan, Y.; Zhang, X.; Liu, C.; Wang, C.; Zhu, H.; Duanmu, D.; Cao, Y.; et al. Suppression of innate immunity mediated by the CDPK-Rboh complex is required for rhizobial colonization in Medicago truncatula nodules. New Phytol. 2018, 220, 425-434. [CrossRef]

62. Skinner, J.S.; von Zitzewitz, J.; Szucs, P.; Marquez-Cedillo, L.; Filichkin, T.; Amundsen, K.; Stockinger, E.J.; Thomashow, M.F.; Chen, T.H.; Hayes, P.M. Structural, functional, and phylogenetic characterization of a large CBF gene family in barley. Plant Mol. Biol. 2005, 59, 533-551. [CrossRef] [PubMed]

63. Gudesblat, G.E.; Torres, P.S.; Vojnov, A.A. Stomata and pathogens: Warfare at the gates. Plant Signal. Behav. 2009, 4, 1114-1116. [CrossRef] [PubMed]

64. Hu, Y.; Cheng, Y.; Yu, X.; Liu, J.; Yang, L.; Gao, Y.; Ke, G.; Zhou, M.; Mu, B.; Xiao, S.; et al. Overexpression of two CDPKs from wild Chinese grapevine enhances powdery mildew resistance in Vitis vinifera and Arabidopsis. New Phytol. 2021, 230, 2029-2046. [CrossRef]

65. Wang, M.; Li, Q.; Sun, K.; Chen, X.; Zhou, Q.; Li, H.; Zhang, X.; Li, X. Involvement of CsCDPK20 and CsCDPK26 in regulation of thermotolerance in tea plant (Camellia sinensis). Plant Mol. Biol. Rep. 2018, 36, 176-187. [CrossRef]

66. Letunic, I.; Khedkar, S.; Bork, P. SMART: Recent updates, new developments and status in 2020. Nucleic Acids Res. 2021, 49, D458-D460. [CrossRef]

67. Ren, J.; Wen, L.; Gao, X.; Jin, C.; Xue, Y.; Yao, X. CSS-Palm 2.0: An updated software for palmitoylation sites prediction. Protein Eng. Des. Sel. 2008, 21, 639-644. [CrossRef]

68. Li, A.; Xue, Y.; Jin, C.; Wang, M.; Yao, X. Prediction of nepsilon-acetylation on internal lysines implemented in bayesian discriminant method. Biochem. Biophys. Res. Commun. 2006, 350, 818-824. [CrossRef]

69. Kumar, S.; Stecher, G.; Tamura, K. MEGA7: Molecular evolutionary genetics analysis version 7.0 for bigger datasets. Mol. Biol. Evol. 2016, 33, 1870-1874. [CrossRef]

70. Hu, B.; Jin, J.; Guo, A.Y.; Zhang, H.; Luo, J.; Gao, G. GSDS 2.0: An upgraded gene feature visualization server. Bioinformatics 2015, 31, 1296-1297. [CrossRef]

71. Fu, C.H.; Chen, Y.W.; Hsiao, Y.Y.; Pan, Z.J.; Liu, Z.J.; Huang, Y.M.; Tsai, W.C.; Chen, H.H. OrchidBase: A collection of sequences of the transcriptome derived from orchids. Plant Cell Physiol. 2011, 52, 238-243. [CrossRef]

72. Sturn, A.; Quackenbush, J.; Trajanoski, Z. Genesis: Cluster analysis of microarray data. Bioinformatics 2002, 18, 207-208. [CrossRef]

73. Gasic, K.; Hernandez, A.; Korban, S.S. RNA extraction from different apple tissues rich in polyphenols and polysaccharides for cDNA library construction. Plant Mol. Biol. Rep. 2004, 22, 437-438. [CrossRef]

74. Zhang, L.; Li, C.; Yang, D.; Wang, Y.; Yang, Y.; Sun, X. Genome-wide analysis of the TCP transcription factor genes in Dendrobium catenatum Lindl. Int. J. Mol. Sci. 2021, 22, 269. [CrossRef] [PubMed]

75. Yang, Y.; Li, X.; Kong, X.; Ma, L.; Hu, X.; Yang, Y. Transcriptome analysis reveals diversified adaptation of Stipa purpurea along a drought gradient on the Tibetan Plateau. Funct. Integr. Genom. 2015, 15, 295-307. [CrossRef] [PubMed] 